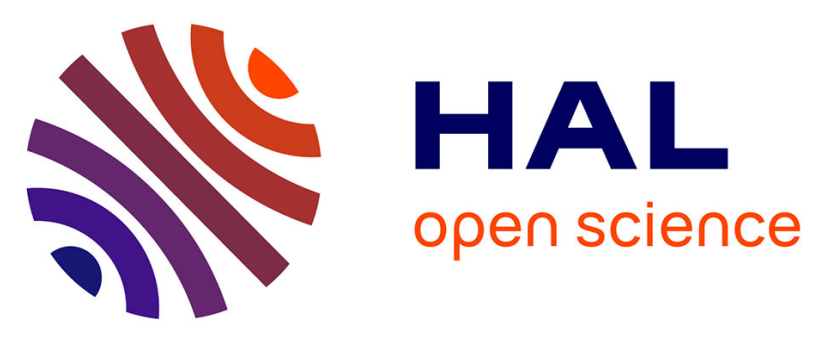

\title{
Synthesis and characterization of novel quinolyl porphyrins as receptors. Study of their association with halophenols and 4nitrophenol as a reference
}

Julie Echaubard, Asmae Bousfiha, Mathieu Berthelot, Julien Roger, Paul

Fleurat-Lessard, Hélène Cattey, Sophie Fournier, Charles H. Devillers,

Dominique Lucas

\section{To cite this version:}

Julie Echaubard, Asmae Bousfiha, Mathieu Berthelot, Julien Roger, Paul Fleurat-Lessard, et al.. Synthesis and characterization of novel quinolyl porphyrins as receptors. Study of their association with halophenols and 4nitrophenol as a reference. European Journal of Inorganic Chemistry, 2020, 2020 (6), pp.551-560. 10.1002/ejic.201900849 . hal-03474545

\section{HAL Id: hal-03474545 \\ https://hal.science/hal-03474545}

Submitted on 10 Dec 2021

HAL is a multi-disciplinary open access archive for the deposit and dissemination of scientific research documents, whether they are published or not. The documents may come from teaching and research institutions in France or abroad, or from public or private research centers.
L'archive ouverte pluridisciplinaire HAL, est destinée au dépôt et à la diffusion de documents scientifiques de niveau recherche, publiés ou non, émanant des établissements d'enseignement et de recherche français ou étrangers, des laboratoires publics ou privés. 


\title{
Synthesis and characterization of novel quinolyl porphyrins as receptors. Study of their association with halophenols and 4- nitrophenol as a reference.
}

\author{
Julie Echaubard, ${ }^{[a]}$ Asmae Bousfiha, ${ }^{[a]}$ Mathieu Berthelot, ${ }^{[a]}$ Julien Roger, ${ }^{[a]}$ Paul Fleurat-Lessard, ${ }^{[a]}$ \\ Hélène Cattey, ${ }^{[a]}$ Sophie Fournier, ${ }^{[a]}$ Charles H. Devillers, ${ }^{*[a]}$ and Dominique Lucas ${ }^{*[a]}$
}

\begin{abstract}
In this work, new receptors built on the porphyrin scaffold were synthesized for halophenols recognition. A quinolyl group was introduced on the porphyrin's periphery as binding site, to form two series of molecules based on two distinct porphyrin frames and which were obtained in free base and zinc forms. The binding between these porphyrin based receptors and halophenols (2,3,4,6tetrachlorophenol, 2,4,6-trichlorophenol or 2,4,6-tribromophenol) was studied. As established by ${ }^{1} \mathrm{H}$ NMR spectroscopy, the binding constants are in the range of two-digit numbers, which value is correlated with the porphyrin structure (substitutive pattern, form of the free base or $\mathrm{Zn}^{\prime \prime}$ complex) and the pKa of the respective phenol. These data, supplemented by a X-ray structure of one adduct complex, indicate a single interaction between the phenolic proton and the nitrogen of the quinolyl group. The binding with $p$-nitrophenol was tested for comparison. The association constant increases at a scale of one order of magnitude. This net stabilization of the adduct complex in this case is explained by additional hydrogen bonds implying the nitro function, as also witnessed by X-ray diffractometry.
\end{abstract}

\section{Introduction}

Halophenols represent a class of chemicals which may be detrimental on the environment. In first place, they are known to be water contaminants, particularly the 2,4,6-trichlorophenol (2,4,6-TCP) which is recognized as a priority environmental pollutant in several countries. ${ }^{[1]}$ The appearance of these compounds in wine must be also especially surveyed as indicators of the possible development of cork taint, which is one of the most critical organoleptic defects for this beverage. Indeed, halophenols are likely to be transformed into haloanisoles, which are responsible for this off-flavour. The most damaging of them is certainly 2,4,6-trichloroanisole (2,4,6-TCA) owing to its low sensory threshold. ${ }^{[2]}$ But others are frequently related to the same problem including 2,3,4,6-tetrachloroanisole, pentachloroanisole

[a] Dr. J. Echaubard, A. Bousfiha, Dr. M. Berthelot, Dr. J. Roger, Prof. P. Fleurat-Lessard, Dr. H. Cattey, S. Fournier, Dr. C. H. Devillers, and Prof. D. Lucas

Institut de Chimie Moléculaire de l'Université de Bourgogne (ICMUB), CNRS UMR 6302

Université de Bourgogne Franche-Comté, Dijon 21078, France E-mail: charles.devillers@u-bourgogne.fr, dominique.lucas@ubourgogne.fr

Supporting information for this article is given via a link at the end of the document. and 2,4,6-tribromoanisole ${ }^{[3]}$. Their generation occurs by microbiological O-methylation of the corresponding halophenols ${ }^{[4-}$ 6]. The risk of contamination by halophenols is due to their use as bactericides, fungicides or flame retardants in the wine making industry. Alternatively, chlorophenols can be formed through reactions between lignin degradation products and free chlorine or chlorinated anionic species contained in solutions used to bleach cork and wash barrels ${ }^{[2]}$.

Therefore, highly selective and sensitive analytical methods are required for the detection and quantitation of halophenols in the environment. Gas chromatography-based techniques coupled with various detectors such as mass spectrometry (MS) or electron capture (ECD) are mostly used for this purpose ${ }^{[2]}$ In view of the complexity of aqueous matrices (especially wine) and since concentrations are usually low, efficient extraction and preconcentration steps are often needed. Pizarro et al. ${ }^{[7-8]}$ applied headspace solid-phase microextraction before introduction in the GC-MS/MS. Other extraction methods are reported including stir bar sorptive extraction ${ }^{[9]}$ and liquid-liquid microextraction. ${ }^{[10]}$ In this respect, there is much interest in developing new efficient receptors for binding halophenols, and on which basis better performing sorptive materials could be synthesized.

In 2003, Mizutani et al. ${ }^{[11]}$ reported the synthesis of functionalized porphyrins and their use as phenol receptors. The addition of a quinolyl group on the porphyrin ring was shown to be an effective strategy for recognition of acidic phenols like $p$-nitrophenol for instance. According to the authors, the strength of this association was proceeding from two synergetic interactions in the adduct complex: 1) hydrogen bonding between the phenol $\mathrm{OH}$ group and the nitrogen base of the quinolyl substituent; 2) $\pi-\pi$ stacking mutually involving the aromatic moieties of the phenol and porphyrin compounds. Notably, pentafluorophenol, a halophenol with no real environmental concern, was the only tested in the reaction with the proposed receptors.

In the present report, new porphyrin-based halophenol receptors containing a 8-quinolyl substituent were prepared (Scheme $1 \mathrm{~A}$ ). Their synthesis and characterization are described. Their affinity towards four halophenols (Scheme 1B) selected for their ecological impact were measured by means of ${ }^{1} \mathrm{H}$ NMR titration experiments, establishing the stoichiometry of the host-guest complexes as well as the values of binding constant. The results are compared with those obtained for 4-nitrophenol, which was also studied by Mizutani et al. ${ }^{[11]}$ The influence of structural features on both the porphyrins and halophenols are discussed 


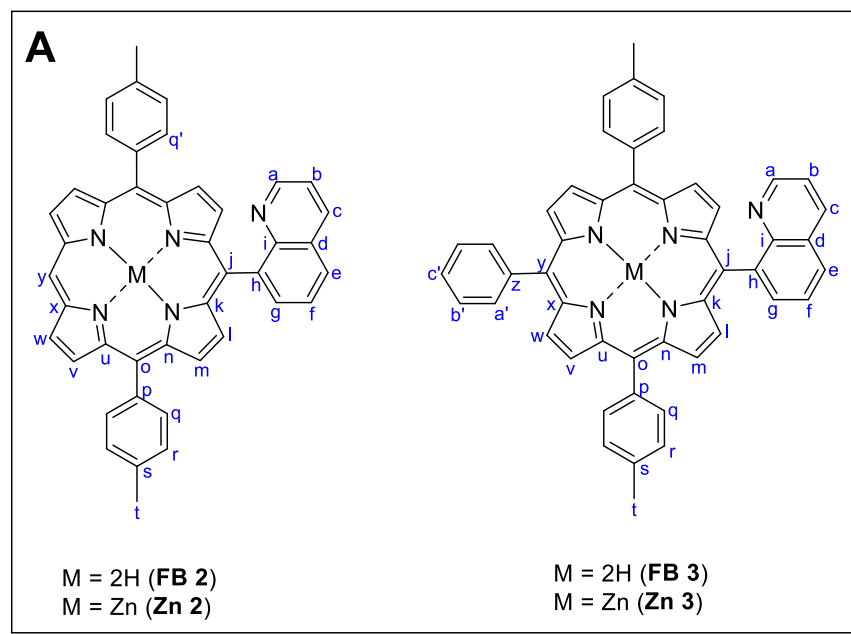

Scheme 1. Porphyrin-based receptors (A) and studied halophenols (B).

and interpreted on the basis of the NMR results and also of X-ray structures of two of the complexes.

\section{Results and Discussion}

\section{Synthesis of porphyrin-based receptors}

Four porphyrins being substituted by one 8-quinolyl group (Scheme 1A) were prepared for the purpose of halophenol recognition. They were obtained both in the free-base and zinc(II) forms. Two kinds of compounds were synthesized starting from 5,15-bis(p-tolyl)porphyrin (FB 1 on Scheme 2) as platform. (2) has a free meso position and one meso 8-quinolyl substituent whereas (3) bears one meso-phenyl and one meso-quinolyl fragments. As an advantage over the receptors reported by Mizutani, the remaining free meso position in $\mathbf{2}$ is a chance for introducing an additional recognition site or grafting function at the periphery of the macrocycle.

These porphyrins were synthesized according to Scheme 1. FB 1 was prepared as reported in the literature. ${ }^{[12]}$ Reaction of FB 1 with a substoichiometric amount of $n$-bromosuccinimide (NBS, 0.8 eq.) was performed in order to maximize the formation of the monobrominated porphyrin (5)..$^{[13-14]}$ However, despite these precautions, a mixture of FB 1, mono (5) and dibrominated (4) products was systematically obtained. Because $\mathbf{5}$ could not be isolated from FB $\mathbf{1}$ and 4, the subsequent Suzuki cross-coupling reaction was directly performed with this mixture and 8quinolineboronic acid pinacol ester in a 50:50 mixture of dimethylformamide (DMF) and toluene in the presence of cesium carbonate as base. Although FB 1 could be removed by column chromatography on silica, we did not manage to separate 5,15 -

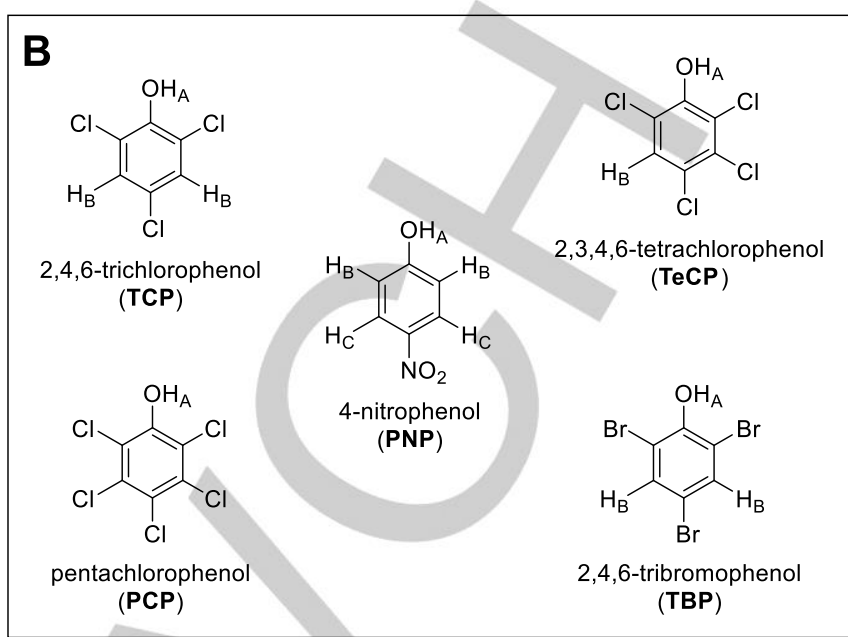

bis(8-quinolyl)-10,20-bis ( $p$-tolyl)porphyrin (6) and 5-(8-quinolyl)10,20 -bis ( $p$-tolyl)porphyrin (FB 2) in these conditions. To increase the solubility of the quinolyl substituted products, these latter were metalated with zinc(II). Thereafter a second purification was carried out by column chromatography on silica, which afforded Zn 2 pure in 30\% yield. Finally, FB 2 was quantitatively obtained by treatment of $\mathbf{Z n} 2$ with trifluoroacetic acid. The sequence giving access to the 3 series is detailed at the bottom of Scheme 2 (steps e to g). Both to increase the solubility and improve the selectivity of the aftercoming reaction steps, a phenyl group was selectively introduced in meso position of FB 1. The reaction was carried out by addition of an excess of phenyllithium at $0^{\circ} \mathrm{C},{ }^{[12]}$ affording 8 in $89 \%$ yield. The remaining unsubstituted meso position of 8 was then brominated with a stoichiometric amount of $n$ bromosuccinimide leading to 9 in $98 \%$ yield. The bromoporphyrin $\mathbf{9}$ was then transformed into FB $\mathbf{3}$ in $88 \%$ yield by a Suzuki crosscoupling reaction with 8-quinolineboronic acid pinacol ester in tetrahydrofuran (THF) in the presence of cesium carbonate as base. Zinc(II) insertion was carried out by reaction with zinc(II) acetate in a 10:1 chloroform/methanol mixture, affording Zn $\mathbf{3}$ in $91 \%$ yield. All compounds were characterized by NMR and highresolution mass spectroscopy.

The ${ }^{1} \mathrm{H}$ NMR spectra of free base porphyrins were recorded in $\mathrm{CDCl}_{3}$. As the ${ }^{1} \mathrm{H}$ NMR spectra of $\mathbf{Z n} \mathbf{2}$ and $\mathbf{Z n} \mathbf{3}$ show unresolved peaks in $\mathrm{CDCl}_{3}$, their spectra have been recorded in deuterated tetrahydrofuran. The protons at the meso position for compounds FB 2 and Zn 2 have a chemical shift of 10.2 ppm. Moreover, the signals of the beta pyrrolic protons range from 8.5 to $9.3 \mathrm{ppm}$ for compounds FB 2 and $Z \mathbf{Z n}$ and from 8.5 to 8.9 ppm for FB $\mathbf{3}$ and $\mathrm{Zn} \mathrm{3.} \mathrm{The} \mathrm{protons} \mathrm{associated} \mathrm{to} \mathrm{the} \mathrm{quinolyl} \mathrm{group} \mathrm{resonate}$ between 7.3 and $8.6 \mathrm{ppm}$, they were allocated on the basis of the ${ }^{13} \mathrm{C}$ and $2 \mathrm{D}$ spectra. In fact, it is assumed that carbon $\mathbf{b}$ is the most shielded one and carbon a the most unshielded. ${ }^{[15]}$ 


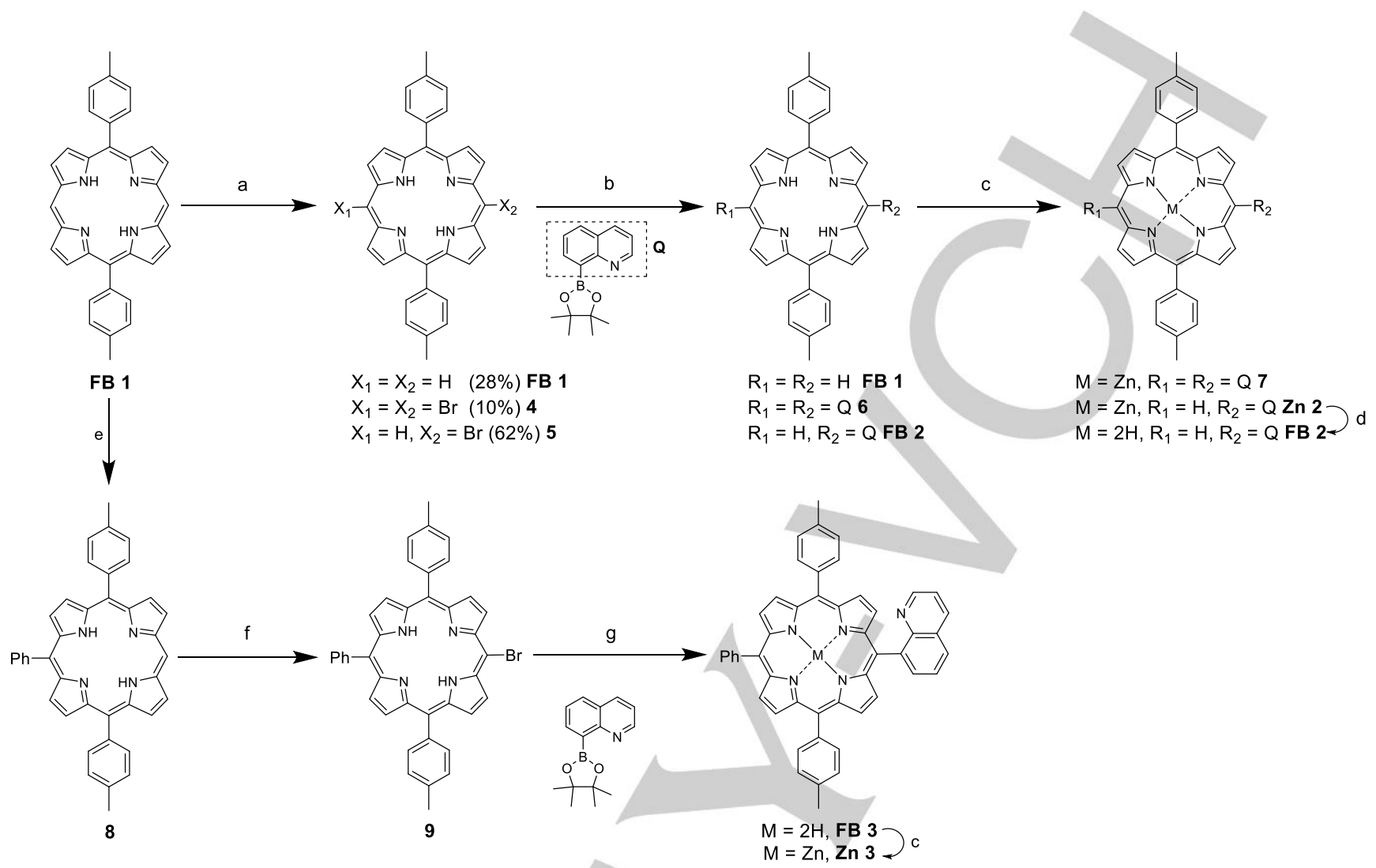

Reagents: (a) NBS (0.8 eq.)/ $\mathrm{CHCl}_{3}$; (b) $[\mathrm{PdCl} \text { (allyl) }]_{2}$ (0.026 eq. per $\mathrm{Br}$ function), 8 -quinolineboronic acid pinacol ester (1.5 eq.), $\mathrm{PPh}$ ( 0.15 eq. per $\mathrm{Br}$ function), $\mathrm{Cs}_{2} \mathrm{CO}_{3}$ (3 eq. per Br function)/DMF/Toluene; (c) $\mathrm{Zn}(\mathrm{OAc})_{2} .2 \mathrm{H}_{2} \mathrm{O}$ (2 eq.)/CHCl $3 / \mathrm{MeOH}$; (d) TFA (18 eq.)/ $\mathrm{CH}_{2} \mathrm{Cl}_{2}$, then NH (aq); (e) phenyllithium (6 eq.)/THF, then DDQ (4 eq.); (f) NBS (1 eq.)/ $\mathrm{CHCl}_{3}$; (g) 8 -quinolineboronic acid pinacol ester (2 eq.), $[\mathrm{PdCl}(\text { allyl })]_{2}(0.025$ eq. $), \mathrm{PPh}_{3}(0.15$ eq. $), \mathrm{Cs}_{2} \mathrm{CO}{ }_{3}(3 \mathrm{eq}$.) $/ \mathrm{THF}$.

Scheme 2. Synthesis of porphyrin-based receptors.

\section{Binding of porphyrin-based receptors to phenols}

To establish the stoichiometry of the association between the studied phenols and porphyrin-based receptors, Job's method experiments were carried out by ${ }^{1} \mathrm{H}$ NMR spectroscopy with 2,4,6trichlorophenol. ${ }^{[16]}$ Aliquots of solution of TCP (or porphyrin) were added in a fixed volume of an equimolar solution of porphyrin (or TCP). The interaction between TCP and quinoline was also studied as reference for comparison with porphyrins. Addition of FB 1 to TCP did not induce any modification in the signals positions of both compounds, which indicates an absence of interaction. Tetraphenylporphyrin (TPP), one of the most common representatives of this family of compounds, was also tested in the addition on TCP: similarly, no significant shift of any signal was noted in the NMR spectrum. Conversely, the addition on TCP of quinoline or any of the porphyrins bearing a quinolyl group causes the signal of the $\mathrm{OH}_{\mathrm{A}}$ signal to move downfield (see Figure S31 right in the Supporting Information as a typical case). Moreover, together with this unshielding, a net broadening of the signal is noted. On an opposite way, the aromatic $\mathrm{H}_{B}$ protons move upfield and the magnitude of the signal shift is all the more large since the relative excess of receptor is important (see Figure
S31 left). The shifts of the porphyrin signals were not significant taking into account that the concentration variation can affect them in the same magnitude. The product of the molar ratio and the variation of chemical shift was plotted as a function of the molar ratio of TCP resulting in a bell-shaped curve with a maximum reached at a ratio of 0.5 (Figure 1). This result is consistent with a 1:1 complex association and all combinations of TCP/Receptor give similar results (see Supporting Information). Zn 2 was not tested because of its poor solubility. The 1:1 stoichiometry was then assumed for all studied phenols.

The binding constants between the diverse receptors and phenols were determined by ${ }^{1} \mathrm{H}$ NMR titration in $\mathrm{CDCl}_{3}$ at $25^{\circ} \mathrm{C}$. The signal of the benzenic $\mathrm{H}_{\mathrm{B}}$ protons of the halophenol was selected for such purpose. Indeed, as described above, its chemical shift undergoes a large variation upon addition of the receptor but without suffering a progressive disappearing like for the phenol $\mathrm{OH}_{\mathrm{A}}$ protons. Nevertheless, the former signal was not useable in two specific cases: first, with quinoline as receptor, to which addition the $\mathrm{H}_{B}$ protons of TCP are practically insensitive; second, and more evidently, with pentachlorophenol (PCP) as guest as it contains no benzenic proton at all. 


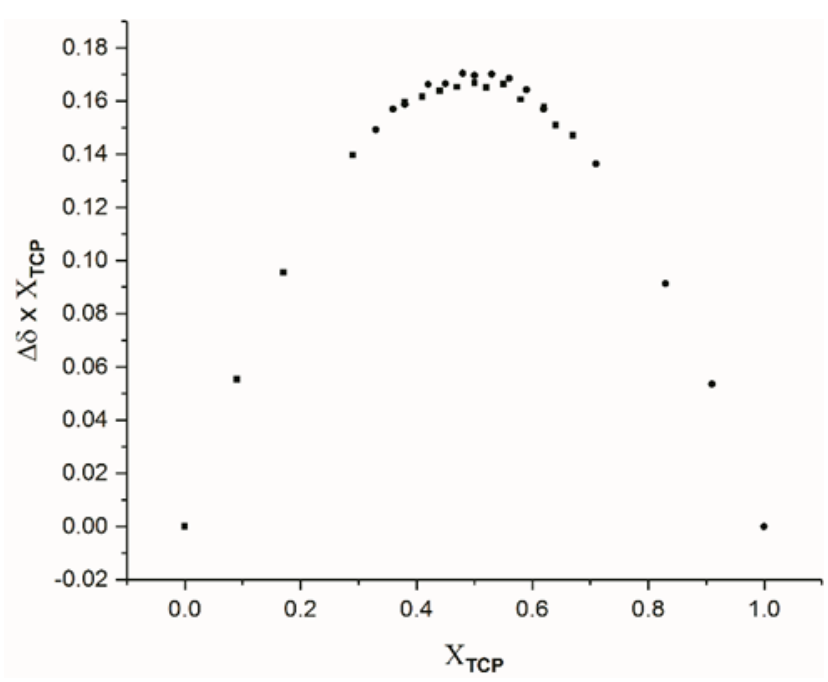

Figure 1. Job's Plot of interaction between TCP and FB 3, variation of chemical shift of $\mathrm{H}_{\mathrm{B}}$ as a function of TCP molar fraction.

For each titration, $\Delta \delta\left(\Delta \delta=\delta_{\text {observed }}-\delta_{0}\right.$, with $\delta_{0}$ being the chemical shift obtained for the free phenol) is plotted against the ratio [receptor]/[phenol] (see Figure 2). Thereafter, the binding constant $\mathrm{K}$ is extracted by fitting this plot assuming a $1: 1$ stoichiometry. This numeric simulation affords also the chemical shift of the phenol $H_{B}$ protons in the complexed form. The maximum chemical shift variation is then defined by:

$$
\Delta \delta_{\max }=\delta_{\text {complex }}-\delta_{0}
$$

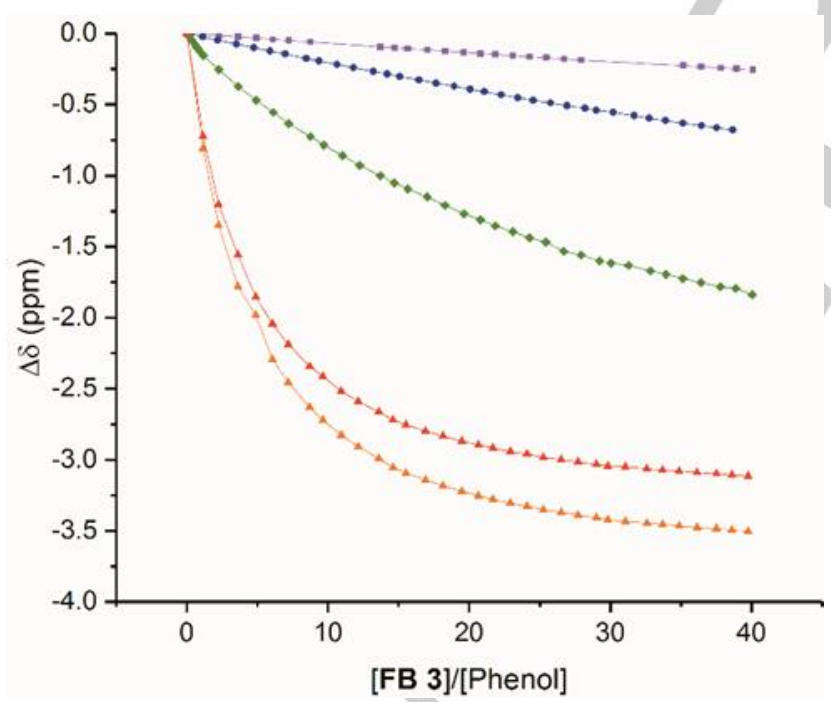

Figure 2. ${ }^{1} \mathrm{H}$ NMR titration plots in $\mathrm{CDCl}_{3}$ of TBP (purple);TCP (blue); TeCP (green); $\mathrm{H}_{\mathrm{B}} \mathrm{PNP}$ (red); $\mathrm{H}_{\mathrm{C}}$ PNP (orange) by FB 3 at $25^{\circ} \mathrm{C}$.

The resulting values of $K$ are gathered in Tables 1 and 2. By considering the data of Table 1, whereas FB 1 or TTP does not show any interaction with TCP, FB 2 and FB 3 exhibit similar affinities for this phenol derivative, with $\mathrm{K}$ values of 11.43 and
12.63 and $\Delta \bar{\delta}_{\max }$ of -3.47 and $-3.38 \mathrm{ppm}$, respectively. Thus, the presence of a phenyl group at the meso position opposite to the quinolyl unit does not affect the binding constant. The binding constant with quinoline falls in the same order of magnitude (10.01) suggesting that the aromatic macrocycle of the porphyrin participates only slightly in stabilizing the complex. In light of this observation, the quinolyl moiety seems to be the only contributor to the association with TCP. Finally, by introducing zinc(II) at the center of porphyrin (FB $\mathbf{3} \rightarrow \mathbf{Z n} \mathbf{3}$ ) the value of $\mathrm{K}$ is increased by nearly a factor of 2 (Table 1 ).

Table 1. Binding constants between receptors and phenol derivatives in $\mathrm{CDCl}_{3}$ at $25^{\circ} \mathrm{C}$

\begin{tabular}{lll} 
& \multicolumn{2}{c}{ K[a] } \\
\cline { 2 - 3 } & 2,4,6-trichlorophenol & p-nitrophenol \\
\hline FB 1 or TPP & Not bound & \\
FB 2 & $11.43( \pm 0.07)$ & $545.8( \pm 2.0)$ \\
FB 3 & $12.63( \pm 0.02)$ & $1218.5( \pm 11.2)$ \\
Zn 3 & $22.46( \pm 0.28)$ & \\
Quinoline & $10.01( \pm 0.10)$ & \\
\hline
\end{tabular}

[a] Estimated uncertainties indicated between brackets.

Table 2. Binding constants between receptor FB $\mathbf{3}$ and phenols.

\begin{tabular}{lll}
\hline & $\mathbf{K}^{[\mathrm{a}]}$ & $\mathbf{p K}$ \\
\hline Pentachlorophenol & not calculated & $4.74^{[17]}$ \\
2,3,4,6-tetrachlorophenol & $72.04( \pm 0.70)$ & $5.22^{[17]}$ \\
2,4,6-trichlorophenol & $12.63( \pm 0.02)$ & $5.99^{[17]}$ \\
2,4,6-tribromophenol & $6.30( \pm 0.02)$ & $6.80^{[18]}$ \\
p-nitrophenol & $545.8( \pm 2.0)$ & $7.15^{[19]}$ \\
\hline
\end{tabular}

[a] Estimated uncertainties indicated between brackets.

Excluding pentachlorophenol, which could not be exploited (see above), the values of $\mathrm{K}$ range from 6.30 to 72.04 . Clearly, the more acidic the phenol is, the higher is the binding constant. More finely, by examining the experimental plot of Figure 3, it seems likely that a linear relationship exists between $\log \mathrm{K}$ and $\mathrm{pKa}$. All together, the data tend to confirm an association based on pure hydrogen bonding between the phenol and the nitrogen base of the quinolyl group. Nevertheless, although the porphyrin does not participate in stabilizing the complex, it contributes in a better precision in the extraction of $\mathrm{K}$ by inducing a large variation in the chemical shift associated to the protons of the benzenic core of the halophenols. The latter are located in the anisotropic cone of the porphyrin and therefore are sensitive to the local magnetic field generated by its ring current. As a consequence, the NMR 
signal gets shielded, a trend which has been verified for all studied halophenols.

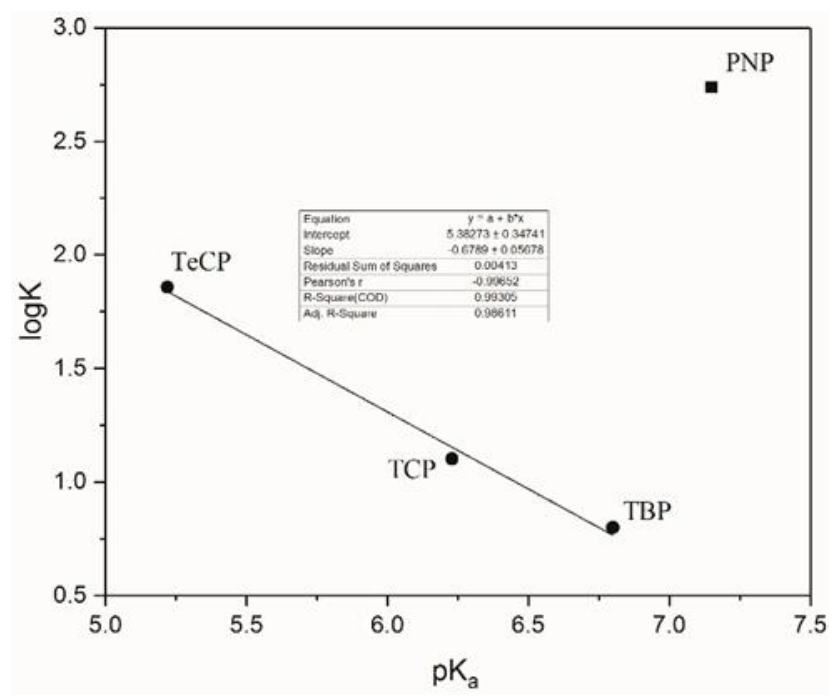

Figure 3. Plot of log $\mathrm{K}$ as a function of $\mathrm{pKa}$ as deduced from the data of Table 2.
As the affinities of $\mathbf{2}$ and $\mathbf{3}$ derivatives towards halophenols were weaker than expected, the titration of $p$-nitrophenol by FB $\mathbf{3}$ was undergone as a reference test. The value of $K$ was estimated at 545.8 , at a similar level as reported by Mizutani et al. ${ }^{[11]}$ That is by far larger than what is predicted by the linear plot of Figure 3 , which demonstrates that an additional stabilizing interaction applies in this circumstance. By titrating with the zinc(II) porphyrin instead of the free base, the binding constant is nearly two times higher, which variation is not appreciably different from the case of trichlorophenol.

\section{X-ray crystallographic structures}

To get a better understanding of the possible interactions between the phenols and the quinolyl-porphyrins, numerous crystallization conditions were tested starting from solutions with a 1:1 phenol/quinolyl-porphyrin ratio. One Zn 3.PNP co-crystal[20] obtained by slow evaporation of a dichloromethane/ $n$-heptane mixture was suitable for X-ray crystallography diffraction analysis. It should be noted that, to the best of our knowledge, Zn 3.PNP represents the first quinolyl-porphyrin $\mathrm{X}$-ray crystallographic structure ever published. Besides, this co-crystal is the first porphyrin structure which is associated with a nitrophenol molecule. The tri-dimensional views of Zn 3.PNP are presented in Figure 4 and Figure 5.

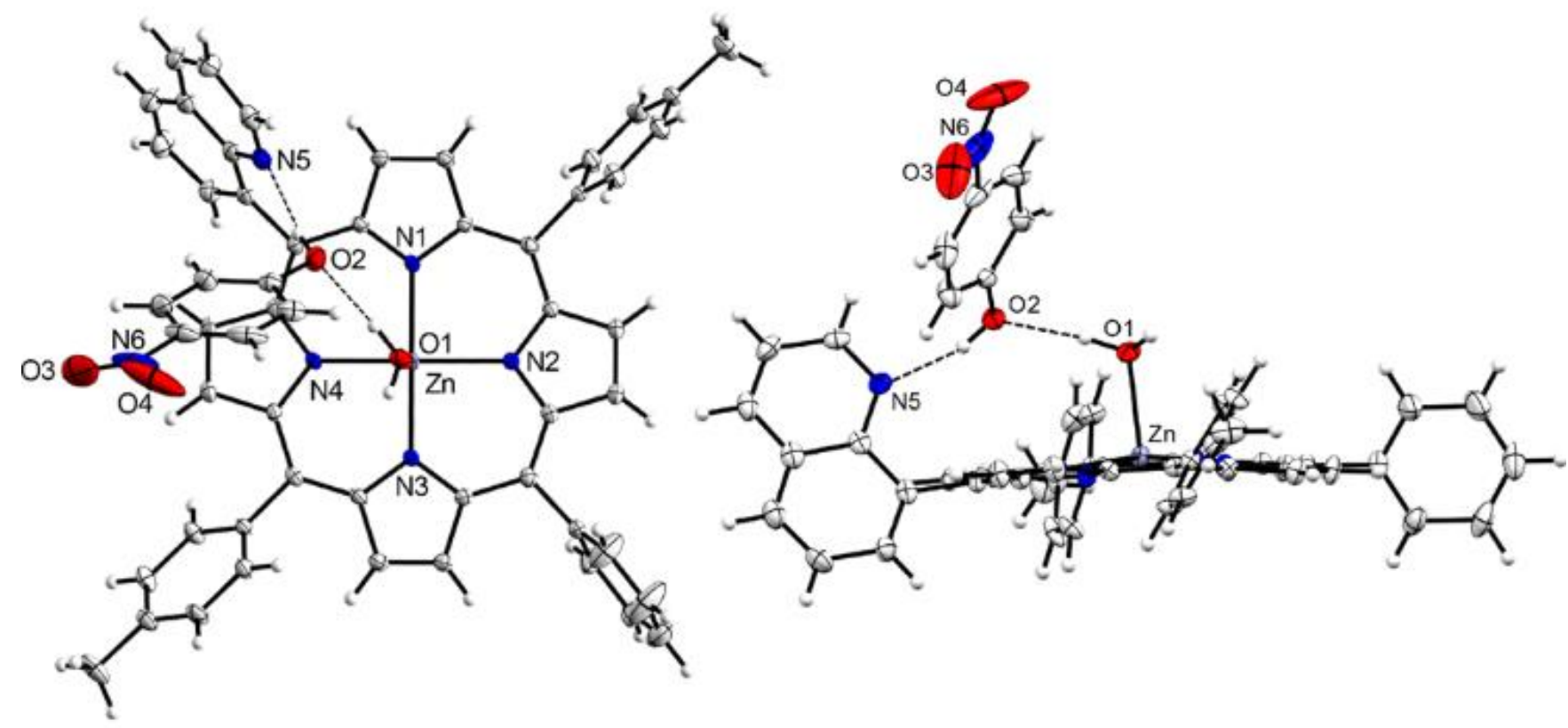

Figure 4. Front (left) and side (right) Mercury views of Zn 3.PNP X-ray crystallographic structure (CCDC 1919134). Thermal ellipsoids are scaled to the 50\% probability level. 


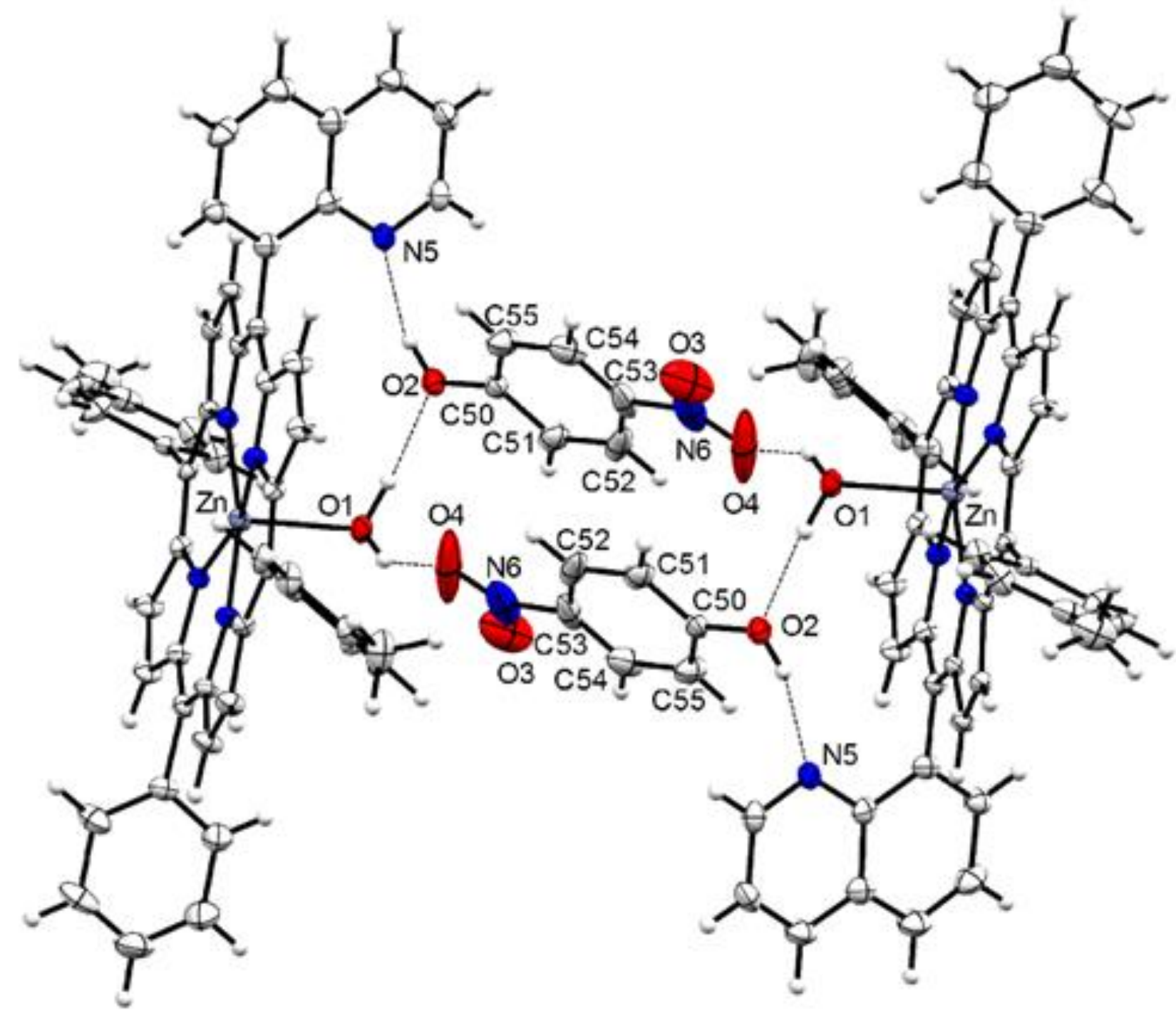

Figure 5. Mercury view of the H-bonded porphyrin dimer seen in Zn 3.PNP (CCDC 1919134). Thermal ellipsoids are scaled to the 50\% probability level.

As expected, a Zn 3/PNP 1:1 ratio is observed in the X-ray crystallographic structure. However, unexpectedly, the zinc(II) atom is coordinated by one apical water molecule $(d(\mathrm{Zn}-\mathrm{O} 1)=$ 2.162(2) ̊̊). This water molecule interacts via two H-bonds with an oxygen atom $(\mathrm{O} 4)$ from the nitro function of PNP $(d(\mathrm{O} 1$ $\mathrm{H} 1 \mathrm{~B} \cdots \mathrm{O} 4)=3.004(5) \AA$ ) and with the oxygen atom $(\mathrm{O} 2)$ from the alcohol function of another PNP molecule $(d(\mathrm{O} 1-\mathrm{H} 1 \mathrm{~A} \cdots \mathrm{O} 2)=$ 2.854(4) $\AA$ ). This latter is also $\mathrm{H}$-bonded with the nitrogen atom (N5) from the quinolyl moiety $(d(\mathrm{O} 2-\mathrm{H} 2 \cdots \mathrm{N} 5)=2.680(4) \AA)$. Globally, two porphyrins relate by an inversion center form an $\mathrm{H}$ bonded dimer (Figure 6) involving two $\mathrm{H}_{2} \mathrm{O}$ ligands and two PNP molecules. These nitrophenol molecules form an head-to-tail $\pi$ stacked dimer with an interplanar distance of 3.373(3) A. The metal-nitrogen (from the porphyrin ring) distance is $2.047(2) \leq$
$d(\mathrm{Zn}-\mathrm{N}) \leq 2.078(2) \AA$. The RMS deviation, i.e. the root mean square of the distances of the 24 carbon and nitrogen porphyrin ring atoms from the mean plane formed by these atoms is 0.078 $\AA$. The torsion angle C2-C1-C21-C29 between the porphyrin and the quinolyl fragment is $-68.1(4)^{\circ}$.

A FB 3.TCP co-crystal obtained by slow evaporation of a dichloromethane/n-pentane mixture was suitable for X-ray crystallography diffraction analysis. The tri-dimensional views of FB 3.TCP are presented in Figure 6. As expected, a FB 3:TCP $1: 1$ ratio is observed in the $X$-ray crystallographic structure. The TCP is $\mathrm{H}$-bonded with the nitrogen atom (N5) from the quinolyl moiety $(\mathrm{d}(\mathrm{O} 1-\mathrm{H} 1 \cdots \mathrm{N} 5)=2.835(6) \AA)$ which indicates a weaker interaction than for the Zn 3:PNP adduct or even with the pyridine moiety of $4,4^{\prime}-($ ethene-1,2-diyl)dipyridine $(\mathrm{d}(\mathrm{O}-\mathrm{H} \cdots \mathrm{N})=2.694(2)$ 
A). ${ }^{[21]}$ The RMS deviation, i.e. the root mean square of the distances of the 24 carbon and nitrogen porphyrin ring atoms from the mean plane formed by these atoms is $0.155 \AA$. The quinolylporphyrin torsion angle is close to the orthogonality (C20-C1-C21$\left.\mathrm{C} 26=88.0(5)^{\circ}\right)$. Interestingly, the TCP moiety is m-stacked with the porphyrin core. The distance between the centroid formed by the carbon atoms of the TCP and the mean plane formed by the 24 carbon and nitrogen porphyrin ring atoms is 3.354(3) $\AA$. Besides, two weak interactions between chlorine and carbon atoms from the porphyrin $(\mathrm{d}(\mathrm{Cl} 1 \cdots \mathrm{C} 15)=3.403(4) \AA$ and $d(C \mid 3 \cdots C 3)=3.401(4) \AA$ ) are observed.
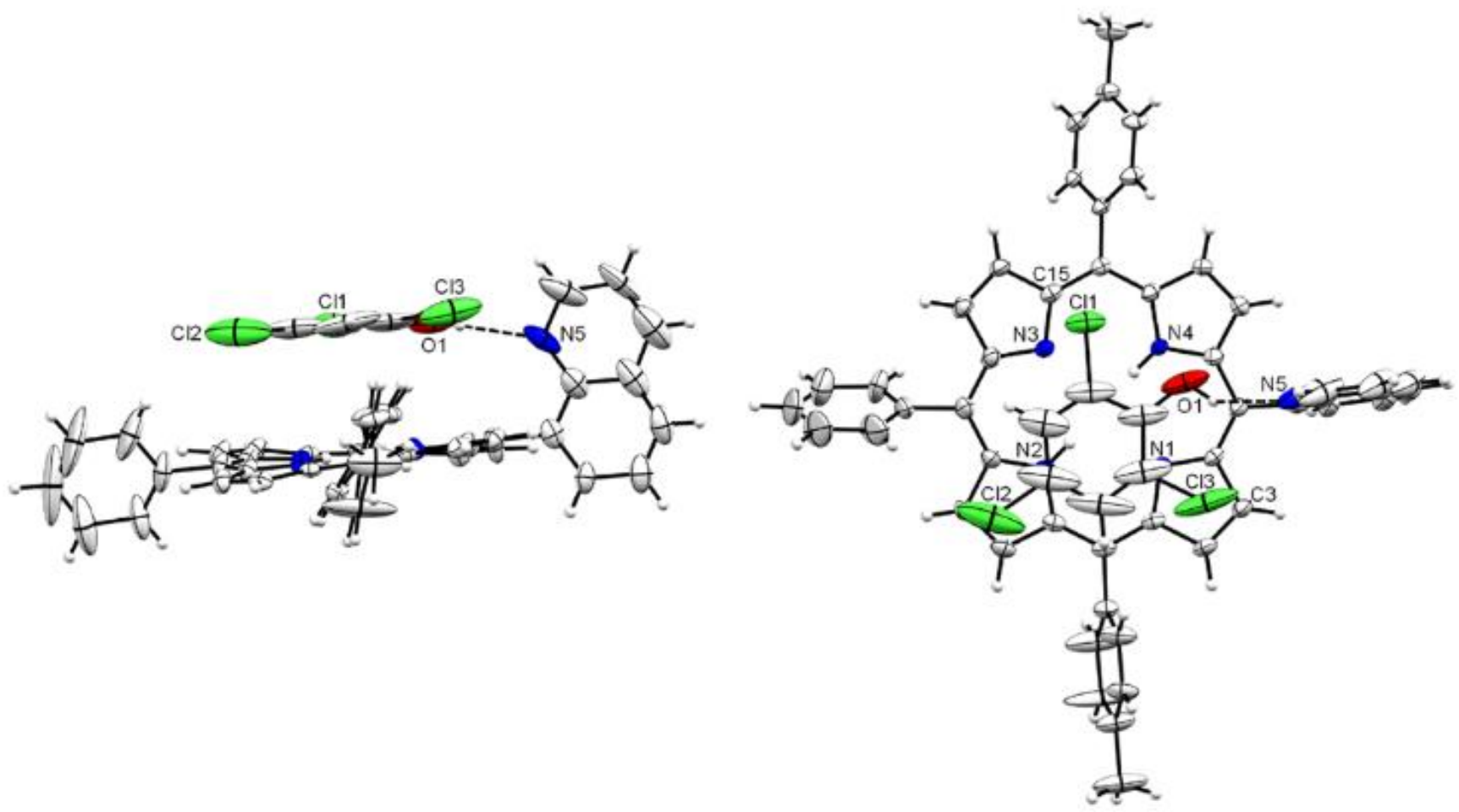

Figure 6. Side (left) and front (right) Mercury views of FB 3.TCP X-ray crystallographic structure (CCDC 1919135). Thermal ellipsoids are scaled to the 50\% probability level.

\section{Interactions conditioning the complex stability}

The molecular structures of the phenol adduct complexes, as revealed by X-ray diffractometry (XRD), are in conformity with the titrations' results. Thus, FB 3.TCP and Zn 3.PNP exhibit a 1:1 stoichiometry as also obtained by the Job's plot experiments. Additionally the XRD analysis of the latter shows that a $\mathrm{H}_{2} \mathrm{O}$ unit makes the connection between the $\mathrm{Zn}$ (II) center and PNP, which was unexpected. In a strict manner, what is observed in the crystal structure doesn't necessarily reflect the equilibrated situation that prevails in solution. But several observations seem to indicate that this three-partner complex is also the one formed in the NMR titration experiments. First, $\mathrm{CDCl}_{3}$ contains systematically traces of residual water, and always in excess versus the studied phenol (ratio comprised between 20 and 60, typically). Moreover, as established in the crystal, the inclusion of $\mathrm{H}_{2} \mathrm{O}$ in Zn 3.PNP generates new interactions which participate in stabilizing the complex; that could explain the large increase of $K$ as measured by NMR.
In order to corroborate this hypothesis, we have especially scrutinized how was evolving the signal of water in the course of the NMR titration experiments. For illustrating this point, Tables 3 and 4 give, for all tested phenol/receptor couples, the variation of $\delta \mathrm{H}_{2} \mathrm{O}$ between the beginning of the titration (in presence of phenol but no receptor still added) and the end (in presence of phenol plus 40 eq. of receptor added). First, a net unshielding of the $\mathrm{H}_{2} \mathrm{O}$ signal is noted with quinoline as receptor $(+0.46 \mathrm{ppm})$, which can be regarded as the effect of hydrogen bonding between these two moieties. Conversely, the addition of the quinolyl porphyrin in the free base form induces a slight shielding, in the range of -0.08$0.09 \mathrm{ppm}$ whatever is the porphyrin (FB 2 or FB 3) or the phenol. In this case, the shift of $\delta \mathrm{H}_{2} \mathrm{O}$ should be the result of two antagonist contributions: 1) hydrogen bonding with the nitrogen base of the quinolyl group (causing unshielding); 2) location of $\mathrm{H}_{2} \mathrm{O}$ in the anisotropic cone of the porphyrin (causing shielding, see above). In accordance with this proposal, we noticed that, during the course of the titration, the higher the porphyrin concentration is, the larger is the shift of $\delta \mathrm{H}_{2} \mathrm{O}$. Incidentally, the 
shielding of the water signal is observed in a similar manner by introducing in $\mathrm{CDCl}_{3}$ FB 2 or FB 3 alone, e.g. in the absence of phenol.

During the titrations, this reaction of water with the quinolyl receptor advances in parallel to the one of phenol. Therefore, it was important to demonstrate that this concurrent reaction had no influence on the titrations' results and that we could be confident in the deduced values of $K$. Therefore, we carried out titrations for which $\mathrm{CDCl}_{3}$ was thoroughly purified in order to minimize water contamination. By this way, according NMR, the amount of water is reduced by one order of magnitude but the exploited signal of the titrated phenol is not affected leaving a value of $K$ basically unchanged.

Table 3. Variation of the chemical shift of water in the titration of TCP and PNP by the quinoline-based receptors (from 0 to 40 eq. added) in $\mathrm{CDCl}{ }_{3}$ at $25^{\circ} \mathrm{C}$.

\begin{tabular}{|c|c|c|}
\hline & \multicolumn{2}{|c|}{$\Delta \delta H_{2} 0(p p m)$} \\
\hline & 2,4,6-trichlorophenol & p-nitrophenol \\
\hline FB 2 & -0.08 & \\
\hline FB 3 & -0.08 & -0.09 \\
\hline Zn 3 & -0.29 & -0.21 \\
\hline Quinoline & +0.46 & \\
\hline
\end{tabular}

Table 4. Variation of the chemical shift of water in the titration of phenol derivatives by $\mathrm{FB} 3$ (from 0 to 40 eq. added) in $\mathrm{CDCl}_{3}$ at $25^{\circ} \mathrm{C}$

\begin{tabular}{ll}
\hline & $\boldsymbol{\Delta} \boldsymbol{\delta}_{\mathbf{2}} \mathbf{O}(\mathbf{p p m})$ \\
\hline 2,3,4,6-tetrachlorophenol & -0.09 \\
2,4,6-trichlorophenol & -0.08 \\
2,4,6-tribromophenol & -0.09 \\
p-nitrophenol & -0.09 \\
\hline
\end{tabular}

Importantly, it must be underlined that the shielding of the water signal is even larger with $\mathbf{Z n} \mathbf{3}$ in comparison to FB $\mathbf{3}$ (see Table 1). This difference may be explained by a supplementary contribution to the average position of the $\mathrm{H}_{2} \mathrm{O}$ signal, which could be for instance $\mathrm{H}_{2} \mathrm{O}$ coordinated to $\mathrm{Zn}(\mathrm{II})$ in the phenol complex, as in the one characterized by XRD.

This proposition of an $\mathrm{H}_{2} \mathrm{O}$-mediated interaction inside the porphyrin's cavity differs from Mizutani et al.'s hypothesis, according which "charge-transfer interaction ( $\pi-\pi$ stacking) between the porphyrin and the aromatic moiety of the guest (PNP) would provide the driving force for the complex formation" (exact citation). ${ }^{[11]}$ Indeed, this kind of interaction should apply in the same way for the halophenols in which the benzenic core is similarly electron-poor. This is not what is observed experimentally since, on one hand, the affinities of quinolyl porphyrins and quinoline alone towards TCP are nearly the same and, on the other hand, in the absence of quinoline as substituent on porphyrin, there is no interaction at all.

For the free base FB 3, the progression of the association constant value between TCP and PNP is also much large (multiplication factor: 43.2), which is similar to the case of $\mathbf{Z n} 3$ (54.2). So, in the absence of $\mathrm{Zn}$ (II) at the porphyrin centre, and therefore of coordinated $\mathrm{H}_{2} \mathrm{O}$ as binder, what should be the interaction at the origin of the gain in stability? We believe that the pyrrole $\mathrm{N}-\mathrm{H}$ units could play the same role by forming hydrogen bonds with the nitro groups of PNP. Such kind of interaction has already been proposed to be involved in the recognition and detection of nitroaromatic explosives. ${ }^{[22-23]}$ Truly, we have no experimental evidence for this hypothesis. We tried hardly to get a single crystal suitable for XRD analysis but until presently with no success.

\section{Conclusions}

A series of porphyrins carrying an 8-quinolyl group at the periphery have been synthesized, characterized and tested in their association with acidic phenols. With halophenols the interaction is essentially based on a single hydrogen bond between the quinolyl nitrogen and the phenolic proton. While the porphyrin part of the receptor does not directly participate in this association, it proved to be useful by exerting a magnetic influence on the trapped phenol, which amplifies the shift of the NMR signal exploited in the titrations. Apart from this advantage the association constants remain rather low and we are now exploring new molecular architectures with the aim to bind halophenols in a more efficient manner, which was our primary objective.

The results with $p$-nitrophenol are certainly the most promising. Our kind of receptor provides a high degree of association with this compound. Most importantly, the combined use of NMR titration and X-ray diffractometry tends to prove that the strength of the association stems from multiple hydrogen bonding, in particular between the nitro function of PNP and the hydrogen atoms of either $\mathrm{a}_{2} \mathrm{O}$ molecule coordinated at the porphyrin metal centre or the pyrrole $\mathrm{N}-\mathrm{H}$ units of the porphyrin in the free base form. Although this type of bonding has been frequently mentioned in the literature, until now, it had never been substantiated by an X-ray resolved molecular structure. The significant association constant found for $\mathbf{Z n} \mathbf{3}$ with $p$-nitrophenol opens the door to new applications and devices in explosive 
detection, as recently reviewed by Senge. ${ }^{[22]}$ Indeed, thanks to the free meso position of $\mathbf{2}$, it will be possible to increase this value by addition of a supplementary recognition site or to immobilize the receptor onto an electrode surface through introduction of a grafting function, such as diazonium for instance. ${ }^{[2]}$

\section{Experimental Section}

\section{Reagents and instrumentation}

THF was dried over alumina cartridges using a solvent purification system PureSolv PS-MD65 model from Innovative Technology and kept under argon. All other solvents used for reactions were obtained from commercial suppliers and used as received. TLC were carried out on Merck TLC Silica gel 60 F-254 aluminium sheets. Column chromatography purifications were performed on silica gel $\left(\mathrm{SiO}_{2}, 40-63 \mu \mathrm{m}\right)$ from SigmaAldrich (technical grade). 2,4,6-trichlorophenol (98\%), 2,3,4,6tetrachlorophenol, pentachlorophenol (97\%) and 2,4,6-tribromophenol (99\%) were purchased from Sigma-Aldrich, 4-nitrophenol (99\%) was purchased from Acros Organics ; all were used without any further purification. 5,15-bis( $p$-tolyl)porphyrin (FB 1) was synthesized according to known procedures. ${ }^{[12,25]}$

${ }^{1} \mathrm{H}$ and ${ }^{13} \mathrm{C}$ spectra were recorded either on a Bruker Avance 300, on a Bruker Avance 500 or on a Bruker Avance 600 III HD spectrometer. Chemical shifts are expressed in parts per million $(\mathrm{ppm})$ from the residual non-deuterated solvent signal. UV-visible absorption spectra were recorded on a VARIAN Cary 50 UV-Visible spectrophotometer using quartz cells. Regarding X-ray diffraction analysis, the equipment and procedure are fully described in the Supporting Information.

\section{Job's and Titration Experiments}

Job's method is a commonly used procedure to determine the stoichiometry of complexes in solution. [26] In this work, Job's experiments were performed with 2,4,6-trichlorophenol in combination with the different receptors of interest (FB 1, FB 2, FB 3, Zn 3 and quinoline). Individual solutions of TCP and of these receptors (R) were initially prepared in $\mathrm{CDCl}_{3}$, (all at the concentration of $2 \times 10^{-2} \mathrm{M}$ ). For each experiment, a set of 30 defined mixtures were achieved by adding aliquots of the solution of TCP (or $\mathrm{R}$ ) in an initial volume $(500 \mu \mathrm{L}$ ) of the solution of $\mathrm{R}$ (or TCP). In this way, the sum of concentrations $\left(\mathrm{C}_{T C P}+\mathrm{C}_{\mathrm{R}}\right)$ is maintained strictly constant while the ratio $\left(\mathrm{C}_{T C P} / \mathrm{C}_{\mathrm{R}}\right)$ varies continuously.

The ${ }^{1} \mathrm{H}$ NMR spectra of all mixed solutions were recorded. The variation of chemical shift for the observed TCP proton $(\mathrm{Hb}$ for the experiments with FB 2, FB 3 and Zn 3; Ha for the experiment with quinoline) was deduced from

$$
\Delta \delta=\delta-\delta_{0}
$$

where $\delta$ is the observed chemical shift and $\delta_{0}$ is the initial chemical shift of free TCP (without receptor in solution). Observed chemical shifts were the weighted average values of the one of free and bound compound. The product of $\Delta \delta$ by the molar fraction of TCP, $\chi \mathrm{TCP}$, was plotted as a function of $\chi$ TCP. According to the literature, a maximum on the plot at the abscissa of 0.5 indicates a $1: 1$ stoichiometry in the adduct complex. ${ }^{[16]}$

For the titration experiments, a solution in $\mathrm{CDCl}_{3}$ of the studied halophenol named $S 1\left(5 \times 10^{-4} \mathrm{M}\right)$ and a solution of the associated receptor in $S 1$, named $S 2\left(2 \times 10^{-2} \mathrm{M}\right)$, were prepared. The progression in the complexation advancement was achieved by adding aliquots of solution $S 1$ (or S2) in an initial volume $(500 \mu \mathrm{L}$ ) of $S 2$ (or $S 1)$. In this way, the concentration of the halophenol is kept constant. The ${ }^{1} \mathrm{H}$ NMR spectra of the resulting solutions were recorded. $\Delta \delta$ was calculated in the same manner as detailed above.
$\Delta \delta$ was then plotted against the halophenol/receptor ratio. Binding constants were evaluated by fitting the titration plot by the Nelder-Mead method using an online fitting tool Bindfit. [27]

\section{Synthesis and characterization}

\section{5-bromo-10,20-bis( $p$-tolyl)porphyrin (5)}

A solution of $\mathrm{FB} 1(1.503 \mathrm{~g}, 3.06 \mathrm{mmol})$ in $\mathrm{CHCl}_{3}(975 \mathrm{~mL})$ was cooled to $0^{\circ} \mathrm{C}$. NBS ( $436.1 \mathrm{mg}, 2.45 \mathrm{mmol}, 0.8 \mathrm{eq}$.) was then added and the reaction mixture was stirred at $0^{\circ} \mathrm{C}$ for 12 minutes, monitoring the progress of the reaction by $\mathrm{TLC}\left(\mathrm{SiO}_{2}, \mathrm{CH}_{2} \mathrm{Cl}_{2}\right.$, n-heptane $\left.(7: 3, \mathrm{v} / \mathrm{v})\right)$. Acetone $(75 \mathrm{~mL})$ was added and the solvent was evaporated. The crude mixture was precipitated in a $\mathrm{CH}_{2} \mathrm{Cl}_{2} / \mathrm{MeOH}$ mixture and filtrated under vacuum. The solid was washed with $\mathrm{MeOH}$ and dried at $120^{\circ} \mathrm{C}$ under vacuum for 3 hours to give $1.677 \mathrm{~g}$ of a mixture of 5 (62\%), 5,15-dibromo-10,20( $p$ tolyl)porphyrin $4(10 \%)$ and FB $1(28 \%)$. The following reaction was directly performed with this mixture.

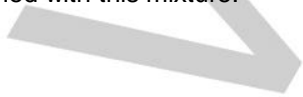

\section{[5-(8-quinolyl)-10,20-bis(p-tolyl)pophyrinato]zinc (Zn 2)}

A degassed solution of allyl palladium chloride dimer $(23.6 \mathrm{mg}, 0.0645$ $\mathrm{mmol}, 0.026$ eq. per Br function) and triphenylphosphine (97.5 mg, 0.371 $\mathrm{mmol}, 0.15$ eq. per $\mathrm{Br}$ function ) in DMF ( $30 \mathrm{~mL}$ ) was added under argon to a mixture of 8-quinolineboronic acid pinacol ester $(947.7 \mathrm{mg}, 3.71 \mathrm{mmol}$, 1.5 eq. per Br function), cesium carbonate $(2.421 \mathrm{~g}, 7.42 \mathrm{mmol}, 3$ eq. per Br function) and the previous mixture containing 5 in a Schlenk flask. DMF $(270 \mathrm{~mL})$ and toluene $(300 \mathrm{~mL})$ were then added. The solution was degassed under argon during $45 \mathrm{~min}$ and stirred at $120^{\circ} \mathrm{C}$ for 4 days. The solvent was evaporated and the crude product was purified by column chromatography $\left(\mathrm{SiO}_{2}, \mathrm{CHCl}_{3} / \mathrm{THF}\right.$ 99.5:0.5). Two fractions were collected containing FB 1 (Fraction A1) and a mixture of FB 2 and 5,15-bis(8quinolyl)-10,20-bis( $p$-tolyl)porphyrin 6 (Fraction A2). We did not manage to separate FB 2 from 6 on this gram scale reaction due to their poor solubility. The solvent of fraction $\mathrm{A} 2$ was evaporated and $\mathrm{Zn}(\mathrm{OAc}) 2.6 \mathrm{H}_{2} \mathrm{O}(0.954 \mathrm{~g}$, $4.35 \mathrm{mmol})$ was added with $\mathrm{CHCl}_{3}(200 \mathrm{~mL})$ and $\mathrm{MeOH}(20 \mathrm{~mL})$. The solution was stirred at $60^{\circ} \mathrm{C}$ for $1.5 \mathrm{~h}$ and washed with water $(3 \times 150 \mathrm{~mL})$. The organic phase was evaporated. The crude product was purified by column chromatography $\left(\mathrm{SiO}_{2}\right.$, toluene/ $\mathrm{MeOH} / \mathrm{Et}_{3} \mathrm{~N}$ 96:3:1). Three fractions were collected containing a mixture of $\mathrm{Zn} 2$ and $\alpha, \beta-5,15$-bis(8quinolyl)-10,20-bis( $p$-tolyl)porphyrin (Fraction B1), Zn 2 (Fraction B2) and $\beta, \beta \quad$ 5,15-bis(8-quinolyl)-10,20-bis( $p$-tolyl)porphyrin (Fraction B3). The fraction B2 was evaporated and then precipitated in a THF $/ n$-heptane mixture. After filtration, the solid was dried at $150^{\circ} \mathrm{C}$ under vacuum for 5 hours to give $\mathrm{Zn} 2$ in $30 \%$ yield $\left(627.4 \mathrm{mg}, 9.21 \times 10^{-1} \mathrm{mmol}\right) .{ }^{1} \mathrm{H} \mathrm{NMR}(500$ $\mathrm{MHz}$, [D8]THF, $300.0 \mathrm{~K}): \delta=10.17\left(\mathrm{~s}, 1 \mathrm{H}\right.$; meso, y), $9.34\left(\mathrm{~d},{ }^{3} \mathrm{~J}-\mathrm{H}=4.3 \mathrm{~Hz}\right.$ $2 \mathrm{H}$; $\beta$-pyrrole, w), 8.98 (d, ${ }^{3} \mathrm{H}-\mathrm{H}=4.3 \mathrm{~Hz}, 2 \mathrm{H} ; \beta$-pyrrole, v), $8.76\left(\mathrm{~d},{ }^{3} \mathrm{~J}-\mathrm{H}\right.$ $=4.5 \mathrm{~Hz}, 2 \mathrm{H} ; \beta$-pyrrole, m), $8.59\left(\mathrm{~d},{ }^{3} \mathrm{~J}_{\mathrm{H}-\mathrm{H}}=7.1 \mathrm{~Hz}, 1 \mathrm{H}\right.$; quinoline, g), 8.51 $\left(\mathrm{d},{ }^{3} \mathrm{~J}_{\mathrm{H}-\mathrm{H}}=4.5 \mathrm{~Hz}, 2 \mathrm{H} ; \beta\right.$-pyrrole, I), $8.46\left(\mathrm{~d},{ }^{3} \mathrm{~J}_{\mathrm{H}-\mathrm{H}}=8.3 \mathrm{~Hz},{ }^{4} \mathrm{~J}_{\mathrm{H}-\mathrm{H}} \approx 1.3 \mathrm{~Hz}\right.$, $1 \mathrm{H}$; quinoline, c), $8.30\left(\mathrm{~d},{ }^{3} \mathrm{JH}_{\mathrm{H}}=8.1 \mathrm{~Hz}, 1 \mathrm{H}\right.$; quinoline, e $), 8.25\left(\mathrm{~d},{ }^{3} \mathrm{JH}_{\mathrm{H}-\mathrm{H}}=\right.$ $3.9 \mathrm{~Hz},{ }^{4} \mathrm{JH}_{\mathrm{H}-\mathrm{H}} \approx 1.3 \mathrm{~Hz}, 1 \mathrm{H}$; quinoline, a), $8.10\left(\mathrm{~d},{ }^{3} \mathrm{~J}-\mathrm{H}=7.6 \mathrm{~Hz}, 2 \mathrm{H}\right.$; tol, q), $8.08\left(\mathrm{~d},{ }^{3} \mathrm{~J}-\mathrm{H}=7.6 \mathrm{~Hz}, 2 \mathrm{H}\right.$; tol, q'), $7.96\left(\mathrm{dd},{ }^{3} \mathrm{H}-\mathrm{H}=7.1 \mathrm{~Hz},{ }^{3} \mathrm{H}-\mathrm{H}=8.1 \mathrm{~Hz}\right.$, $1 \mathrm{H}$; quinoline, f), $7.55\left(\mathrm{~d},{ }^{3} \mathrm{JH}_{\mathrm{H}} \mathrm{H}=7.6 \mathrm{~Hz}, 4 \mathrm{H}\right.$; tol, r), $7.31\left(\mathrm{dd},{ }^{3} \mathrm{JH}_{\mathrm{H}}=8.3\right.$ $\mathrm{Hz},{ }^{3} \mathrm{~J}-\mathrm{H}=3.9 \mathrm{~Hz}, 1 \mathrm{H}$; quinoline, b), $2.68 \mathrm{ppm}\left(\mathrm{s}, 6 \mathrm{H} ; \mathrm{CH}_{3}, \mathbf{t}\right) ;{ }^{13} \mathrm{C}\left\{{ }^{1} \mathrm{H}\right\}$ $\operatorname{NMR}(500 \mathrm{MHz}$, [D8]THF, 298.0 K): $\delta=151.6,151.2,150.9,150.58,150.56$, $150.48,143.8,141.5,137.3,136.3,135.3,135.2,135.1,132.3,131.9$, $131.7,129.0,128.6,127.64,127.57,125.3,121.2,120.4,119.2,105.8$, $21.3 \mathrm{ppm}$; UV-visible $\left(\mathrm{CH}_{2} \mathrm{Cl}_{2}\right): \lambda_{\max }(\log \varepsilon)=300(4.26), 347(4.05), 415$ (5.75), 506 (3.46), 543 (4.34), 579 (3.37) nm; HRMS (ESI+): $\mathrm{m} / \mathrm{z}$ cald for $\mathrm{C}_{43} \mathrm{H}_{29} \mathrm{~N}_{5}: 679.1709$ [M+]; found: 679.1735 . 


\section{5-(8-quinolyl)-10,20-bis(p-tolyl)pophyrin (FB 2)}

A solution of $\mathrm{Zn} 2\left(100.0 \mathrm{mg}, 1.47 \times 10^{-1} \mathrm{mmol}\right)$ in $\mathrm{CH}_{2} \mathrm{Cl}_{2}(20 \mathrm{~mL})$ and TFA $(0.2 \mathrm{~mL}, 2.61 \mathrm{mmol}, 18 \mathrm{eq})$ was stirred for $30 \mathrm{~min}$, monitoring the progress of the reaction by $\mathrm{TLC}\left(\mathrm{SiO}_{2}, \mathrm{CH}_{2} \mathrm{Cl}_{2}\right) .25 \mathrm{~mL}$ of concentrated ammonia solution ( $25 \%$ in water) was poured into the reaction mixture. The organic layer was separated and washed with purified water $(2 \times 25 \mathrm{~mL})$. The solvent was evaporated and the crude product was precipitated in a $\mathrm{CH}_{2} \mathrm{Cl}_{2} / n$-hexane mixture. The solid was dried at $150^{\circ} \mathrm{C}$ under vacuum for 3 hours to give FB 2 in $98 \%$ ( $\left.89.1 \mathrm{mg}, 1.44 \times 10^{-1} \mathrm{mmol}\right) .{ }^{1} \mathrm{H}$ NMR (300 $\mathrm{MHz} \mathrm{CDCl}_{3}, 294.9 \mathrm{~K}$ ): $\delta=10.19\left(\mathrm{~s}, 1 \mathrm{H}\right.$; meso, y), $9.32\left(\mathrm{~d},{ }^{3} \mathrm{~J}_{\mathrm{H}-\mathrm{H}}=4.7 \mathrm{~Hz}\right.$, $2 \mathrm{H}$; $\beta$-pyrrole, w), 9.01 (d, ${ }^{3} \mathrm{~J}_{\mathrm{H}-\mathrm{H}}=4.7 \mathrm{~Hz}, 2 \mathrm{H}$; $\beta$-pyrrole, v), 8.81 (d, ${ }^{3} J_{\mathrm{H}-\mathrm{H}}$ $=4.8 \mathrm{~Hz}, 2 \mathrm{H}$; $\beta$-pyrrole, m), $8.54\left(\mathrm{dd},{ }^{3} \mathrm{~J}_{\mathrm{H}-\mathrm{H}}=4.2 \mathrm{~Hz},{ }^{4} J_{\mathrm{H}-\mathrm{H}}=1.8 \mathrm{~Hz}, 1 \mathrm{H}\right.$; quinoline, a), $8.53\left(\mathrm{~d},{ }^{3} \mathrm{~J}_{\mathrm{H}-\mathrm{H}}=4.8 \mathrm{~Hz}, 2 \mathrm{H}\right.$; $\beta$-pyrrole, I), 8.51 (dd, ${ }^{3} \mathrm{~J}_{\mathrm{H}-\mathrm{H}}=7.1$ $\mathrm{Hz},{ }^{4} \int_{\mathrm{H}-\mathrm{H}}=1.4 \mathrm{~Hz}, 1 \mathrm{H}$; quinoline, g), $8.45\left(\mathrm{dd},{ }^{3} \mathrm{~J}_{\mathrm{H}-\mathrm{H}}=8.3 \mathrm{~Hz},{ }^{4} \mathrm{~J}_{\mathrm{H}-\mathrm{H}}=1.8\right.$ $\mathrm{Hz}, 1 \mathrm{H}$; quinoline, c), $8.29\left(\mathrm{dd},{ }^{3} \mathrm{~J}_{\mathrm{H}-\mathrm{H}}=8.3 \mathrm{~Hz},{ }^{4} \mathrm{~J}_{\mathrm{H}-\mathrm{H}}=1.4 \mathrm{~Hz} ; 1 \mathrm{H}\right.$; quinoline, e), $8.10\left(\mathrm{~m}, 4 \mathrm{H}\right.$; tol, q), $7.94\left(\mathrm{dd},{ }^{3} \mathrm{~J}_{\mathrm{H}-\mathrm{H}}=8.3 \mathrm{~Hz},{ }^{3} \mathrm{~J}_{\mathrm{H}-\mathrm{H}}=7.1 \mathrm{~Hz}, 1 \mathrm{H}\right.$; quinoline, f), $7.55\left(\mathrm{~d},{ }^{3} \mathrm{~J}_{\mathrm{H}-\mathrm{H}}=8.3 \mathrm{~Hz}, 4 \mathrm{H}\right.$; tol, r), $7.38\left(\mathrm{dd},{ }^{3} \mathrm{~J}_{\mathrm{H}-\mathrm{H}}=8.3 \mathrm{~Hz}\right.$, ${ }^{3} \mathrm{~J}_{\mathrm{H}-\mathrm{H}}=4.2 \mathrm{~Hz}, 1 \mathrm{H}$; quinoline, b), $2.70\left(\mathrm{~s}, 6 \mathrm{H} ; \mathrm{CH}_{3}, \mathbf{t}\right),-2.80 \mathrm{ppm}(\mathrm{s}, 2 \mathrm{H}$; $\mathrm{NH}) ;{ }^{13} \mathrm{C}\left\{{ }^{1} \mathrm{H}\right\}$ NMR $\left(500 \mathrm{MHz}, \mathrm{CDCl}_{3}, 300.0 \mathrm{~K}\right): \delta=150.9,150.4,147.0$ (beta), 141.9; 139.1, 137.4, 136.1, 135.8, 134.8, 131.3, 131.0, 128.9, 128.0 127.6, 125.0, 121.0, 119.7, 117.7, 104.9, 21.6 ppm; UV-visible $\left(\mathrm{CH}_{2} \mathrm{Cl}_{2}\right)$ : $\lambda_{\max }(\log \varepsilon)=300$ (4.23), 368 (4.39), 413 (5.66), 509 (4.28), 543 (3.76), 583 (3.76), 639 (3.38) nm; HRMS (ESI+): $m / z$ cald for $\mathrm{C}_{43} \mathrm{H}_{32} \mathrm{~N}_{5}: 618.2652$ $[\mathrm{M}+\mathrm{H}]^{+}$; found: 618.2668 .

\section{5,15-bis(p-tolyl)-10-phenylporphyrin (8)}

8 was synthesized as reported in reference ${ }^{[28]}$. 5,15-bis ( $p$-tolyl)porphyrin FB 1 (1.000 g, $2.04 \mathrm{mmol})$ was solubilized in dry THF (300 mL) under argon in a Schlenk flask. The solution was cooled to $0{ }^{\circ} \mathrm{C}$ (ice bath) and phenyllithium $(6.5 \mathrm{~mL}$ of a solution at $1.9 \mathrm{M}$ in di- $n$-butyl ether, $12.4 \mathrm{mmol}$, 6 eq.) was added dropwise. The resulting solution was stirred at $0^{\circ} \mathrm{C}$ for $15 \mathrm{~min}$. After removal of the ice bath, the reaction mixture was stirred for another $15 \mathrm{~min}$ period, followed by addition of a degassed $\mathrm{THF} / \mathrm{H}_{2} \mathrm{O}$ mixture $(100 \mathrm{~mL} / 10 \mathrm{~mL})$. After stirring for $10 \mathrm{~min}$, DDQ $(1.851 \mathrm{~g}, 8.15 \mathrm{mmol}$, 4 eq.) was introduced into the Schlenk flask and the mixture was stirred at room temperature without protection from air for one hour. The resulting purple solution was directly filtered on $\mathrm{Al}_{2} \mathrm{O}_{3}$ pad $(h=10 \mathrm{~cm}, \varnothing=5.5 \mathrm{~cm})$ and it was eluted with $\mathrm{CH}_{2} \mathrm{Cl}_{2}$. The purple solid obtained after removing the solvent was precipitated in $\mathrm{MeOH}$. The precipitate was washed with $\mathrm{MeOH}$ and dried at $120^{\circ} \mathrm{C}$ under vacuum for $3 \mathrm{~h}$ giving 8 in $89 \%$ yield $(1.030 \mathrm{~g}, 1.82 \mathrm{mmol})$. Characterization data were in agreement with those published in reference. ${ }^{[28]}$

\section{5-bromo-10,20-bis(p-tolyl)-15-phenylpophyrin (9)}

A solution of 8 (499.9 mg, $\left.8.82 \times 10^{-1} \mathrm{mmol}\right)$ in $\mathrm{CHCl}_{3}(280 \mathrm{~mL})$ was cooled at $0^{\circ} \mathrm{C}$. NBS $\left(157.1 \mathrm{mg}, 8.83 \times 10^{-1} \mathrm{mmol}, 1\right.$ eq.) was added and the reaction mixture was stirred at $0^{\circ} \mathrm{C}$ for $30 \mathrm{~min}$., monitoring the progress of the reaction by $\mathrm{TLC}\left(\mathrm{SiO}_{2}, \mathrm{CH}_{2} \mathrm{Cl}_{2}, n\right.$-heptane $\left.(6: 4, \mathrm{v} / \mathrm{v})\right)$. Acetone $(50 \mathrm{~mL})$ was then added and the solvent was evaporated. The crude product was precipitated in a $\mathrm{CH}_{2} \mathrm{Cl}_{2} / \mathrm{MeOH}$ mixture. The precipitate was washed with $\mathrm{MeOH}$ and dried at $120^{\circ} \mathrm{C}$ for 3 hours under vacuum to give 9 in $98 \%$ yield (555.7 mg, $\left.8.61 \times 10^{-1} \mathrm{mmol}\right)$. Characterization data were in agreement with those published in reference. ${ }^{[12]}$

\section{5-(8-quinolyl)-10,20-bis(p-tolyl)-15-phenylporphyrin (FB 3)}

A degassed solution of allyl palladium chloride dimer $\left(3.1 \mathrm{mg}, 8.47 \times 10^{-3}\right.$ $\mathrm{mmol}, 0.025$ eq. $)$, triphenylphosphine $\left(13.3 \mathrm{mg}, 5.07 \times 10^{-2} \mathrm{mmol}, 0.15\right.$ eq. $)$ in THF $(2.5 \mathrm{~mL})$ was added under argon to a mixture of $9(217.0 \mathrm{mg}$ $\left.3.36 \times 10^{-1} \mathrm{mmol}\right), 8$-quinolineboronic acid pinacol ester $(171.5 \mathrm{mg}$, $6.72 \times 10^{-1} \mathrm{mmol}, 2$ eq.), and cesium carbonate $(328.8 \mathrm{mg}, 1.01 \mathrm{mmol}, 3$ eq.) in a Schlenk flask. THF $(8.5 \mathrm{~mL})$ was added and the solution was degassed under argon during $10 \mathrm{~min}$. The solution was stirred at $70^{\circ} \mathrm{C}$ for 18 hours. The solvent was evaporated and the residue was purified by column chromatography $\left(\mathrm{SiO}_{2}, \mathrm{CH}_{2} \mathrm{Cl}_{2}\right)$ followed by a precipitation in a $\mathrm{CH}_{2} \mathrm{Cl}_{2} / \mathrm{MeOH}$ mixture. The precipitate was dried at $150^{\circ} \mathrm{C}$ under vacuum for 3 hours to give FB 3 in $88 \%$ yield $\left(205.5 \mathrm{mg}, 2.96 \times 10^{-1} \mathrm{mmol}\right) .{ }^{1} \mathrm{H}$ NMR $\left(500 \mathrm{MHz}, \mathrm{CDCl}_{3}, 297.9 \mathrm{~K}\right): \delta=8.89\left(\mathrm{~d},{ }^{3} \mathrm{~J}_{\mathrm{H}-\mathrm{H}}=4.7 \mathrm{~Hz}, 2 \mathrm{H}\right.$; $\beta$-pyrrole, v) $8.86\left(\mathrm{~d},{ }^{3} \mathrm{~J}_{\mathrm{H}-\mathrm{H}}=4.7 \mathrm{~Hz}, 2 \mathrm{H}\right.$; $\beta$-pyrrole, w), $8.80\left(\mathrm{~d},{ }^{3} \mathrm{~J}_{\mathrm{H}-\mathrm{H}}=4.7 \mathrm{~Hz}, 2 \mathrm{H}\right.$; $\beta$ pyrrole, m), 8.59 (dd, ${ }^{3} \mathrm{~J}_{\mathrm{H}-\mathrm{H}}=4.1 \mathrm{~Hz},{ }^{4} \mathrm{~J}_{\mathrm{H}-\mathrm{H}}=1.7 \mathrm{~Hz}, 1 \mathrm{H}$; quinoline, a), 8.53 $\left(\mathrm{d},{ }^{3} \mathrm{~J}_{\mathrm{H}-\mathrm{H}}=4.7 \mathrm{~Hz}, 2 \mathrm{H}\right.$; $\beta$-pyrrole, I), 8.52 (dd, ${ }^{3} \mathrm{~J}_{\mathrm{H}-\mathrm{H}} 7.0 \mathrm{~Hz}$ (non measurable, by deduction), ${ }^{4} \mathrm{~J}_{\mathrm{H}-\mathrm{H}}=1.4 \mathrm{~Hz}, 1 \mathrm{H}$; quinoline, g), , $8.39\left(\mathrm{dd},{ }^{3} J_{\mathrm{H}-\mathrm{H}}=8.4 \mathrm{~Hz}\right.$, ${ }^{4} J_{\mathrm{H}-\mathrm{H}}=1.7 \mathrm{~Hz}, 1 \mathrm{H}$; quinoline, c), $8.30\left(\mathrm{~d},{ }^{3} \mathrm{~J}_{\mathrm{H}-\mathrm{H}}=6.0 \mathrm{~Hz}, 1 \mathrm{H}\right.$; phenyl, a'), $8.23\left(\mathrm{~d},{ }^{3} \mathrm{~J}_{\mathrm{H}-\mathrm{H}}=6.0 \mathrm{~Hz}, 1 \mathrm{H}\right.$; phenyl, a'), $8.23\left(\mathrm{dd},{ }^{3} \mathrm{~J}_{\mathrm{H}-\mathrm{H}}=8.3 \mathrm{~Hz},{ }^{4} \mathrm{~J}_{\mathrm{H}-\mathrm{H}}=\right.$ $1.4 \mathrm{~Hz}, 1 \mathrm{H}$; quinoline, e), $8.11\left(\mathrm{~m}, 4 \mathrm{H}\right.$; tol, q), $7.92\left(\mathrm{dd},{ }^{3} \mathrm{~J}_{\mathrm{H}-\mathrm{H}}=8.3 \mathrm{~Hz},{ }^{3} \mathrm{~J}_{\mathrm{H}-}\right.$ $\mathrm{H}=7.0 \mathrm{~Hz}, 1 \mathrm{H}$; quinoline, f), $7.78\left(\mathrm{~m}, 3 \mathrm{H}\right.$; phenyl, b'+c'), $7.54\left(\mathrm{~d},{ }^{3} \mathrm{~J}_{\mathrm{H}-\mathrm{H}}=\right.$ $8.1 \mathrm{~Hz}, 4 \mathrm{H}$; tol, r), 7.37 (dd, ${ }^{3} \mathrm{~J}_{\mathrm{H}-\mathrm{H}}=8.4 \mathrm{~Hz},{ }^{3} \mathrm{~J}_{\mathrm{H}-\mathrm{H}}=4.1 \mathrm{~Hz}, 1 \mathrm{H}$; quinoline, b), $2.70\left(\mathrm{~s}, 6 \mathrm{H} ; \mathrm{CH}_{3}, \mathbf{t}\right),-2.53 \mathrm{ppm}(\mathrm{s}, 2 \mathrm{H} ; \mathrm{NH}) ;{ }^{13} \mathrm{C}\left\{{ }^{1} \mathrm{H}\right\} \mathrm{NMR}(500 \mathrm{MHz}$ $\left.\mathrm{CDCl}_{3}, 298.7 \mathrm{~K}\right): \delta=150.9,150.2,142.6,141.4,139.5,137.3,136.2,135.8$, 134.8, 134.6, 130.8 (broad signal), 128.9, 128.0, 127.7, 127.5, 126.8, 125.1, 121.0, 120.23, 120.21, 117.2, 21.6 ppm; UV-visible $\left(\mathrm{CH}_{2} \mathrm{Cl}_{2}\right): \lambda_{\max }$ $(\log \varepsilon)=275$ (4.28), 374 (4.41), 419 (5.74), 515 (4.33), 550 (3.95), 590 (3.80), 646 (3.65) nm; HRMS (ESI+): $\mathrm{m} / z$ cald for C49H36N5: 694.2965 $[\mathrm{M}+\mathrm{H}]^{+}$; found: 694.2982

[5-(8-quinolyl)-10,20-bis(p-tolyl)-15-phenylporphyrinato]zinc (Zn 3)

FB $3\left(100.4 \mathrm{mg}, 1.45 \times 10^{-1} \mathrm{mmol}\right)$ was solubilized in $\mathrm{CHCl}_{3}(13.3 \mathrm{~mL})$ and $\mathrm{Zn}(\mathrm{OAc}) 2.2 \mathrm{H}_{2} \mathrm{O}$ was added $(5 \mathrm{~mL}$ of a saturated solution in $\mathrm{MeOH}$ ). The solution was stirred at $60^{\circ} \mathrm{C}$ for $1 \mathrm{~h} 30$. After evaporation of the solvent, the residue was solubilized in 1,2-dichloroethane $(20 \mathrm{~mL})$ and the solution was washed with purified water heated at $70^{\circ} \mathrm{C}(10 \times 100 \mathrm{~mL})$. The organic phase was evaporated and the crude product was precipitated in $\mathrm{MeOH}$. The precipitate was dried at $150^{\circ} \mathrm{C}$ under vacuum for 3 hours to give $\mathbf{Z n} 3$ in $91 \%\left(100.1 \mathrm{mg}, 1.32 \times 10^{-1} \mathrm{mmol}\right) .{ }^{1} \mathrm{H}$ NMR $(500 \mathrm{MHz}$, [D8]THF, 298.0 $\mathrm{K}): \delta=8.84\left(\mathrm{~d},{ }^{3} \mathrm{~J}_{\mathrm{H}-\mathrm{H}}=4.6 \mathrm{~Hz}, 2 \mathrm{H}\right.$; $\beta$-pyrrole, v), $8.82\left(\mathrm{~d},{ }^{3} \mathrm{~J}_{\mathrm{H}-\mathrm{H}}=4.6 \mathrm{~Hz}, 2 \mathrm{H}\right.$; $\beta$-pyrrole, w), 8.72 (d, ${ }^{3} \mathrm{~J}_{\mathrm{H}-\mathrm{H}}=4.6 \mathrm{~Hz}, 2 \mathrm{H} ; \beta$-pyrrole, m), 8.59 (dd, ${ }^{3} \mathrm{~J}_{\mathrm{H}-\mathrm{H}}=$ $7.1 \mathrm{~Hz},{ }^{4} \mathrm{JH}_{\mathrm{H}-\mathrm{H}}=1.2 \mathrm{~Hz}, 1 \mathrm{H}$; quinoline, g), $8.49\left(\mathrm{~d},{ }^{3} \mathrm{~J}_{\mathrm{H}-\mathrm{H}}=4.6 \mathrm{~Hz}, 2 \mathrm{H}\right.$; $\beta-$ pyrrole, I), $8.46\left(\mathrm{dd},{ }^{3} \mathrm{~J}_{\mathrm{H}-\mathrm{H}}=8.4 \mathrm{~Hz},{ }^{4} \mathrm{~J}_{\mathrm{H}-\mathrm{H}}=1.6 \mathrm{~Hz}, 1 \mathrm{H}\right.$; quinoline, c), 8.30 $\left(\mathrm{dd},{ }^{3} \mathrm{~J}_{\mathrm{H}-\mathrm{H}}=8.3 \mathrm{~Hz},{ }^{4} \mathrm{~J}_{\mathrm{H}-\mathrm{H}}=1.2 \mathrm{~Hz}, 1 \mathrm{H}\right.$; quinoline, e), $8.28\left(\mathrm{dd},{ }^{3} \mathrm{~J}_{\mathrm{H}-\mathrm{H}}=4.0\right.$ $\mathrm{Hz},{ }^{4} \mathrm{~J}_{\mathrm{H}-\mathrm{H}}=1.6 \mathrm{~Hz}, 1 \mathrm{H}$; quinoline, a), $8.22(\mathrm{~m}, 2 \mathrm{H}$; phenyl, a'), $8.06(\mathrm{~m}, 4 \mathrm{H}$ tol, q), $7.96\left(\mathrm{dd},{ }^{3} \mathrm{~J}_{\mathrm{H}-\mathrm{H}}=8.3 \mathrm{~Hz},{ }^{3} \mathrm{~J}_{\mathrm{H}-\mathrm{H}}=7.1 \mathrm{~Hz}, 1 \mathrm{H}\right.$; quinoline, f), $7.73(\mathrm{~m}$ $3 \mathrm{H}$; phenyl, b'+c'), $7.52\left(\mathrm{~d},{ }^{3} \mathrm{~J}_{\mathrm{H}-\mathrm{H}}=8.0 \mathrm{~Hz}, 4 \mathrm{H}\right.$; tol, r), $7.32\left(\mathrm{dd},{ }^{3} J_{\mathrm{H}-\mathrm{H}}=8.4\right.$ $\mathrm{Hz},{ }^{3} \mathrm{~J}_{\mathrm{H}-\mathrm{H}}=4.0 \mathrm{~Hz}, 1 \mathrm{H}$; quinoline, b), $2.66 \mathrm{ppm}\left(\mathrm{s}, 6 \mathrm{H} ; \mathrm{CH}_{3}, \mathbf{t}\right) ;{ }^{13} \mathrm{C}\left\{{ }^{1} \mathrm{H}\right\}$ NMR $(500 \mathrm{MHz}$, [D8]THF, 298.0 K): $\delta=151.7,151.6,150.9,150.7,150.6$ $150.5,144.6,143.7,141.6,137.3,136.3,135.3,135.2,135.12,135.06$, $135.0,131.9,131.84,131.77,131.7,129.0,128.6,127.8,127.6,127.5$, 126.93, 126.86, 125.3, 121.2, 121.1, 121.0, 119.0, 21.3 ppm; UV-visible $\left(\mathrm{CH}_{2} \mathrm{Cl}_{2}\right): \lambda_{\max }(\log \varepsilon)=302$ (4.27), 350 (4.06), 400 (4.65), 420 (5.79), 511 (3.57), 549 (4.37), 586 (3.63) nm; HRMS (ESI+): $m / z$ cald for $\mathrm{C}_{49} \mathrm{H}_{33} \mathrm{~N}_{5} \mathrm{Zn}$ : $755.2022\left[\mathrm{M}^{+}\right]$; found: 755.2054 .

The complete crystallographic data, as well as the detailed procedure for crystal collection and XRD analysis, are provided in the Supporting Information.

\section{Acknowledgments}

This work was supported by the CNRS, Universite de Bourgogne Franche-Comté and the Conseil Régional de Bourgogne through 
the "Plan d'Actions Régional pour l'Innovation (PARI)" and the "Fonds Européen de Développement Régional (FEDER)" programs. The CNRS is specially thanked for funding this research with the "Défi Instrumentation aux limites" program. C. H. D. thanks the CNRS (Sept. 2015, one year "délégation CNRS") and the Agence Nationale de la Recherche for funding (ANR-15-CE29-0018-01). The authors are grateful to Maxime Denis, Emmanuelle Lehoussel and Coraline Duroux for technical support, and Marie-José Penouilh for HRMS analyses. They also thank Michel Meyer who provided insight and expertise on titration experiments, as well Hervé Gibault, from the IOC company, for his attentive interest in this research.

Keywords: quinolyl porphyrins - porphyrin-based receptors • halophenols $\cdot p$-nitrophenol $\bullet$ X-ray crystallographic structures

[1] Y. Zhang, M. Liu, J. Liu, X. Wang, C. Wang, W. Ai, S. Chen, H. Wang, Environ. Toxicol. Pharmacol. 2018, 57, 9-18.

[2] A. R. Fontana, TrAC, Trends Anal. Chem. 2012, 37, 135-147.

[3] P. Chatonnet, S. Bonnet, S. Boutou, M.-D. Labadie, J. Agric. Food Chem. 2004, 52, 1255-1262.

[4] A. Allar, M. Remberger, A. H. Neilson, Appl. Environ. Microbiol. 1987, 53, 839-845.

[5] M. L. Álvarez-Rodríguez, L. López-Ocaña, J. M. López-Coronado, E. Rodríguez, M. J. Martínez, G. Larriba, J.-J. R. Coque, Appl. Environ. Microbiol. 2002, 68, 5860-5869.

[6] J. L. Hill, A. D. Hocking, F. B. Whitfield, Food Chem. 1995, 54, 161-166.

[7] C. Pizarro, N. Perez-del-Notario, J. M. Gonzalez-Saiz, J. Chromatogr. A 2007, 1143, 26-35.

[8] C. Pizarro, N. Perez-del-Notario, J. M. Gonzalez-Saiz, J. Chromatogr. A 2007, 1166, 1-8.

[9] L. Maggi, A. Zalacain, V. Mazzoleni, G. L. Alonso, M. R. Salinas, Talanta 2008, 75, 753-759.

[10] C. Pizarro, N. Perez-Del-Notario, A. Saenz-Mateo, J. M. Gonzalez-Saiz, Talanta 2014, 128, 1-8.

[11] K. Wada, T. Mizutani, S. Kitagawa, J. Org. Chem. 2003, 68, 5123-5131.
[12] B. Habermeyer, A. Takai, C. P. Gros, M. El Ojaimi, J. M. Barbe, S. Fukuzumi, Chem. - Eur. J. 2011, 17, 10670-10681.

[13] M. Berthelot, G. Hoffmann, A. Bousfiha, J. Echaubard, J. Roger, H. Cattey, A. Romieu, D. Lucas, P. Fleurat-Lessard, C. H. Devillers, Chem. Commun. 2018, 54, 5414-5417.

[14] Y. Y. Enakieva, J. Michalak, I. A. Abdulaeva, M. V. Volostnykh, C. Stern, R. Guilard, A. G. Bessmertnykh-Lemeune, Y. G. Gorbunova, A. Y. Tsivadze, K. M. Kadish, Eur. J. Org. Chem. 2016, 2016, 4881-4892.

[15] J.-A. Su, E. Siew, E. V. Brown, S. L. Smith, Org. Magn. Reson. 1977, 10, 122-125.

[16] J. S. Renny, L. L. Tomasevich, E. H. Tallmadge, D. B. Collum, Angew. Chem., Int. Ed. Engl. 2013, 52, 11998-12013.

[17] K. C. Ma, W. Y. Shiu, D. Mackay, J. Chem. Eng. Data 1993, 38, 364-366.

[18] E. P. Serjeant, B. Dempsey, lonisation constants of organic acids in aqueous solution, Vol. 23, Pergamon Press, Oxford, New York, 1979.

[19] M. D. Liptak, K. C. Gross, P. G. Seybold, S. Feldgus, G. C. Shields, J. Am. Chem. Soc. 2002, 124, 6421-6427.

[20] C. A. Gunawardana, C. B. Aakeröy, Chem. Commun. 2018, 54, 1404714060.

[21] G. Campillo-Alvarado, C. Li, D. C. Swenson, L. R. MacGillivray, Cryst. Growth Des. 2019, 19, 2511-2518.

[22] M. Kielmann, C. Prior, M. O. Senge, New J. Chem. 2018, 42, 7529-7550.

[23] N. Venkatramaiah, C. F. Pereira, R. F. Mendes, F. A. A. Paz, J. P. C Tomé, Anal. Chem. 2015, 87, 4515-4522.

[24] S. Hebié, C. H. Devillers, S. Fournier, D. Lucas, ChemElectroChem 2016 , 3, 45-50.

[25] J. K. Laha, S. Dhanalekshmi, M. Taniguchi, A. Ambroise, J. S. Lindsey, Org. Process Res. Dev. 2003, 7, 799-812.

[26] Z. D. Hill, P. MacCarthy, J. Chem. Educ. 1986, 63, 162.

[27] P. Thordarson, Supramolecular, 2015, http://supramolecular.org.

[28] C. H. Devillers, S. Hebié, D. Lucas, H. Cattey, S. Clément, S. Richeter, J. Org. Chem. 2014, 79, 6424-6434. 
Entry for the Table of Contents (Please choose one layout)

Layout 2:

\section{FULL PAPER}

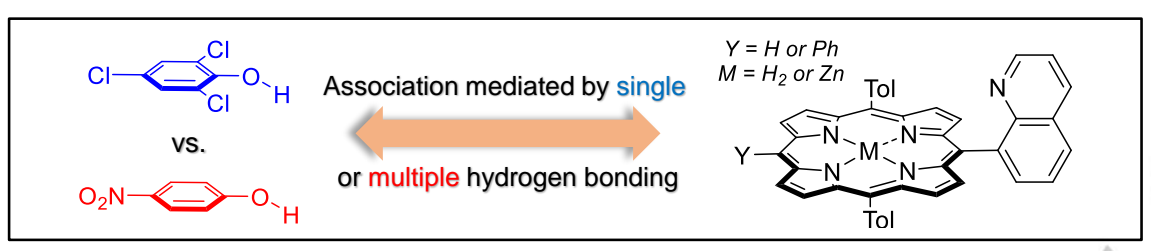

New porphyrins functionalized by a 8-quinolyl group were synthesized as receptors for selected halophenols and p-nitrophenol. The strength of the association and kind of interaction involved in the different couples are emphasized on the basis of ${ }^{1} \mathrm{H}$ NMR titration and X-ray resolved molecular structures of some of the adduct complexes.

\section{Porphyrin-based receptors*}

Julie Echaubard, Asmae Bousfiha, Mathieu Berthelot, Julien Roger, Paul Fleurat-Lessard, Hélène Cattey, Sophie Fournier, Charles H. Devillers ${ }^{\star}$ and Dominique Lucas*

\section{Page No. - Page No.}

Synthesis and characterization of novel quinolyl porphyrins as receptors. Study of their association with halophenols and 4-nitrophenol 